\title{
Maria Teresa Moia, La presenza della realtà nazionale nel simbolismo belga
}

Ida Merello

\section{(2) OpenEdition}

\section{Edizione digitale}

URL: http://journals.openedition.org/studifrancesi/9013

DOI: $10.4000 /$ studifrancesi.9013

ISSN: 2421-5856

\section{Editore}

Rosenberg \& Sellier

\section{Edizione cartacea}

Data di pubblicazione: 1 octobre 2008

Paginazione: 485

ISSN: 0039-2944

\section{Notizia bibliografica digitale}

Ida Merello, «Maria Teresa Moia, La presenza della realtà nazionale nel simbolismo belga», Studi Francesi [Online], 155 (LII | II) | 2008, online dal 30 novembre 2015, consultato il 09 janvier 2021. URL: http:// journals.openedition.org/studifrancesi/9013 ; DOI: https://doi.org/10.4000/studifrancesi.9013

Questo documento è stato generato automaticamente il 9 janvier 2021.

\section{(c) $(1) \&$}

Studi Francesi è distribuita con Licenza Creative Commons Attribuzione - Non commerciale - Non opere derivate 4.0 Internazionale. 


\title{
Maria Teresa Moia, La presenza della realtà nazionale nel simbolismo belga
}

\author{
Ida Merello
}

\section{NOTIZIA}

MARIA TERESA MOIA, La presenza della realtà nazionale nel simbolismo belga, Milano, Università Cattolica, 2007, pp. 336.

Dopo l'esemplare monografia su Maeterlinck di Gorceix, che spaziava a sua volta su tutto il contesto culturale e artistico belga e francese, ecco ora questo ponderoso volume che, partendo dalla tematica suggerita dal titolo, intende offrire un'ampia panoramica delle dinamiche storiche, letterarie e culturali del Simbolismo belga, senza neppure trascurare le arti visive. L'A. parte dall'analisi delle riviste, di cui registra l'evoluzione teorica, dalla parnassiana «Jeune Belgique», al «Coq rouge» verslibriste che le si contrappone, alla simbolista «Wallonie» fino alla socialista "Art Moderne», per poi tentare di misurare in prima istanza l'influenza di filosofi come Schopenhauer e Nietzsche sul panorama culturale dell'epoca, quindi l'influenza religiosa e la sua declinazione in Rodenbach, Maeterlinck, Elskamp, Van Lerberghe, Verhaeren. Per completare il quadro l'A. evidenzia anche la presenza dei modelli delle arti visive in Rodenbach e Van Lerberghe, nonché del Naturalismo e del Simbolismo francese sulla contemporanea letteratura belga. Solo nella seconda parte dell'opera l'A. affronta il tema principale, ossia i rapporti con la storia nazionale belga, indagati nella terza e ultima parte nei loro aspetti spaziali di realtà anche geografica, in luoghi aperti, chiusi, cittadini. Opera ben scritta, di ricchissima bibliografia, soffre un po' forse di un'ambizione troppo enciclopedica: il lettore talvolta amerebbe soffermarsi su qualche aspetto, ma subito è trascinato verso altri luoghi. 